\title{
Seasonal measurement of serum total cholesterol and malondialdehyde in healthy subjects
}

\author{
Mohammad A Al-kataan*, Amani Ibraheem Younis*, Faris A Ahmed** \\ Departments of *Clinical Pharmacy, College of Pharmacy, **Department of Physiology, Ninevah College of \\ Medicine, University of Mosul, Iraq
}

Received Accepted

r.1. Y.1.

$r \cdot .11, r \cdot 1 \cdot$

\begin{abstract}
Objective: To evaluate serum total cholesterol (TC) and malondialdehyde (MDA) in healthy subjects in winter and summer seasons.

Subjects and methods: This study was conducted at the college of Pharmacy, University of Mosul. Twenty healthy subjects, non-smokers, free from any medication were included in this study. Five $\mathrm{mL}$ of blood sample from each subject was taken in winter and other blood sample was taken from the same subject in summer and analysed for serum TC and MDA.
\end{abstract}

Results: No significant difference was noticed between winter and summer for serum TC ( $\left\{. \theta_{ \pm} \cdot . \diamond \mathrm{mmol} / \mathrm{L}\right.$ versus $\left\{.\left\{\theta_{ \pm} \cdot.\right\urcorner \mathrm{mmol} / \mathrm{L}\right)$. However, serum MDA in summer $\left(1.19_{ \pm \cdot} . r \mu\right.$ mole/L) was significantly higher $(P<\cdot .1)$ than in winter $(\cdot .97 \pm \cdot .17 \mu \mathrm{mol} / \mathrm{L})$

Conclusion: Oxidative stress increases in hot weather. Seasonal serum lipid profile levels depend on life style of the people and their geographical location.

الخلاصة

الهدف: لتقييم الكولستيرول الكلي و المالونيالدهايد في مصل الدم في الافر اد الاصحاء في فصلي الصيف الثتاء.

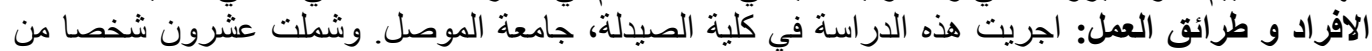

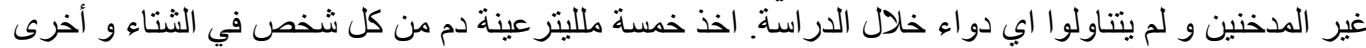

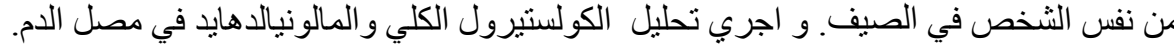

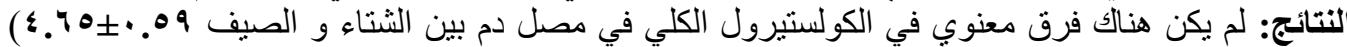

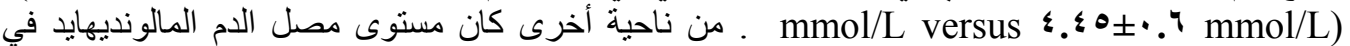

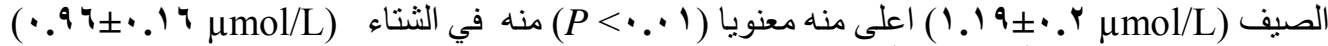

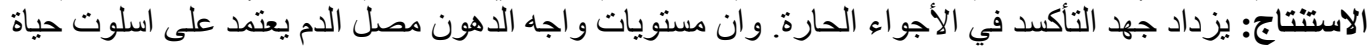

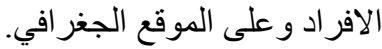

$\mathbf{N}$ umerous human physiological and pathophysiological processes have been reported to vary seasonally in both healthy volunteers and people with chronic diseases. Some of these include adrenaline, lipids, blood pressure and lipid peroxidation ${ }^{\prime-r}$.

Statistically significant seasonal changes in lipid levels have been found in individuals irrespective of the country, and irrespective of the age, sex, ethnicity, and baseline lipid levels of the study subjects ${ }^{\varepsilon}$. However, there are contradictory results regarding the pattern of seasonal variation of serum lipid $^{0,7}$.

Oxidative stress represents an imbalance between the production and manifestation of reactive oxygen species and a biological system's ability to readily detoxify the reactive intermediates or to repair the resulting damage ${ }^{r}$. Disturbances in the normal redox state of tissues can cause toxic effects through the production of peroxides and free radicals that 
damage all components of the cell, including lipids causing lipid

peroxidation ${ }^{\wedge}$. One of the most frequently used biomarkers providing an indication of the overall lipid peroxidation level is the plasma concentration of malondialdehyde ? The seasonal changes for lipid peroxidation were documented but the studies were contradictory. This study was conducted to evaluate the seasonal variation of lipid peroxidation and serum lipid in healthy subjects..

\section{Subjects and methods}

This study was conducted at the College of Pharmacy, University of Mosul. Twenty apparently healthy subjects ( $) \cdot$ males and $1 \cdot$ females) were included in this study. Their ages ranged between $r$ r $r \leqslant$ years (mean \pm SD: $r r_{ \pm} \cdot{ }^{\prime}$ years).The studied subjects were apparently healthy, non smokers and free from any medications.Fasting blood sample $\left({ }^{\circ} \mathrm{ml}\right)$ was taken from each subject and analyzed for serum MDA and TC. The blood samples were taken from the same subjects in winter $r . . \wedge$ (January) and other blood samples were taken from the same subjects in summer $\uparrow \ldots \wedge$ (August). Determination of serum TC was performed by using enzymatic method '. Serum MDA was analyzed by using Buege and Aust method '. . One $\mathrm{ml}$ of the reagent $(\cdot r \vee \circ g$ thiobarbituric acid, and $10 \mathrm{~g}$ trichloroacetic acid dissolved in $\cdot r \circ \mathrm{N}$ $\mathrm{HCl}$ to make $1 \cdots \mathrm{ml}$ ) was added to $\cdot{ }^{\circ}$ $\mathrm{ml}$ of serum. The mixture was mixed and heated in a water bath at $\mathrm{V} \cdot{ }^{\circ} \mathrm{C}$ for 10 minutes and MDA was measured in the supernatant solution by spectrophotometer at orr nm. MDA concentration was calculated by the following equation

MDA conc. $\left(\mu \frac{m b l}{2}\right)=$
$\frac{\text { absorbance of tegt- absorkance of blank }}{\text { XNDA }}$
$* 1 . \top$

$\Sigma$ MDA is equal to molar extension coefficient of $\mathrm{MDA}=1.07 \times 10^{\circ}$ $\mu \mathrm{mol} / \mathrm{cmData}$ are presented by mean \pm SD and were analyzed by using paired t-test. $P<\bullet . \bullet$ was considered significant

\section{Results}

Table) shows that no significant difference was noticed between winter and summer for serum TC in healthy subjects. However, serum MDA in the summer (August) was significantly higher $(P<\cdot \cdot)$ compared with that in the winter (January).

Table . Serum MDA and TC in healthy subjects $(n=r \cdot)$

\begin{tabular}{|c|c|c|}
\hline Seasons & $\begin{array}{c}\text { Serum TC } \\
\mathrm{mmol} / \mathrm{L}\end{array}$ & $\begin{array}{c}\text { Serum MDA } \\
(\mu \mathrm{mol} / \mathrm{L})\end{array}$ \\
\hline $\begin{array}{c}\text { Winter } \\
\text { (January) }\end{array}$ & $\varepsilon .70_{ \pm} .79$ & $\ddots .97 \pm \cdot .17$ \\
\hline $\begin{array}{c}\text { Summer } \\
\text { (August) }\end{array}$ & $\varepsilon .0_{ \pm} \cdot .7$ & $1.19_{ \pm \cdot . \mathrm{Y}^{*}}$ \\
\hline
\end{tabular}

MDA: malondialdehyde; TC: total cholesterol, ${ }^{*} P<\cdot .{ }^{\cdot}$ 


\section{S}

\section{Discussion}

In this study, serum TC did not changed significantly between summer and winter . This result is in agreement with other workers ${ }^{\prime r}$. Many studies found serum lipid in winter is higher than in summer, ${ }^{r}$.

The insignificant change of the present study is not known. In monthly measurement of TC, Kelly showed lowest TC in July and started to increase in August. Therefore the monthly measurements of TC would give more information. The long daily time in summer and increase the activity supported the decrease of cholesterol. The cultural life for food intake and the geographical location may play important role for seasonal changes.

In this study, lipid peroxidation was higher in summer than in winter in the subjects. This study is in agreement with other workers ' . However, smolkova et $\mathrm{al}^{r}$ showed a clear pattern, with high level of plasma MDA in winter/spring and low levels in summer/autumn

This study included only $r$. subjects which was small sample compared with other studies; however, this study could be considered as preliminary study for further investigation in the hospitals, since the seasonal changes of the biochemical parameters are not taken into the consideration.

Questions such as whether the level of TC in winter has the same risk association with cardiovascular endpoints as a similar value in summer, have not been assessed in research studies.

In conclusion, oxidative stress increases in hot weather. Seasonal serum lipid profile levels depend on life style of the people and their geographical location.

\section{Acknowledgments}

The study was supported by the College of Pharmacy, University of Mosul, Iraq.

\section{References}

1- Letllier G, Desjarlasis . Study of seasonal variations for eighteen biochemical parameters over a four-year period. Clin Bioch 19Nr; 0:r. T_l1.

r- Donahoo WT, Jensen DR, Shepard TY et al. Seasonal variation in lipoprotein lipase and plasma lipids in physically active, normal weight humans. JCEM r...; ; $0_{0} r \cdot 70_{-} \wedge$.

r. Smolkova B, Dusinska M, Raslova $\mathrm{K}$, et al. Seasonal changes in markers of oxidative damage to lipids and DNA; correlations with seasonal variation in diet. Mutat Res. Y.. $\varepsilon ; 1 r: 001: 1$ ro_ $\varepsilon \varepsilon$.

¿ - Kelly GS. Seasonal variations of selected cardiovascular risk factors. Alternative medicine review $r \cdot .0 ; 1 \cdot ; r \cdot v_{-} r \cdot$.

๑_ Fuller JH. Grainger SL, Jarrett RJ, et al. Possible seasonal variation of plasma lipids in a healthy population. Clin Chim Acta 19Vะ;0Y:r.0-1.

7. Hadaegh F, Harati H, Zavetian A, et al. Seasonal variability of serum lipids in adults: Tehran lipid and glucose study. Med J Malaysia r.. T;T):TrT_A.

V - Halliwell B. The of oxygen radicals I human disease, with particular reference to the vascular system. Haemostasis 199r;rr(suppl 1): 1) A_r 7 .

^. Gutteridge GMC. Lipid peroxidation as biomarkers in tissue damage. Clin chem. $1990 ; \varepsilon 1: 111 \tau_{-} \mathrm{r}$.

9. Gawel S, Wardas M, Niewozok E, et al. Malondialdehyde (MDA) as a 
lipid preoxidation maker. Wiad

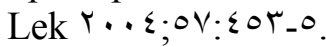

1.-Buege JA, Aust SD. Microsomal lipid peroxidation. Methods

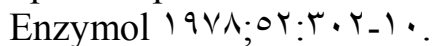

1)-Stein EA, Myers GL. Lipid, Apolipoproteins and lipoproteins. In; Burtis CA, Ashood ER. Teitz fundamentals of Clinical Chemistry. $\varepsilon^{\text {th }}$ Ed. Philadelphia:

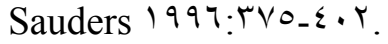

Ir-Woodhouse PR, Khaw KT, Plummer M. Seasonal variation of serum lipids in an elderly population. Age Aging 199r;Yr:YVT_A.
1 T-Gordon DJ, Trost DC, Hyde J, et al. Seasonal cholesterol cycles: the Lipid Research Clinics Coronary Primary Prevention Trial placebo group. Circulation I $9 \wedge \vee ; \vee \tau: I Y Y \varepsilon_{-}$ T).

1 \&-Morera AL, Intxausti A, AbreuGonzalez P. Winter/summer seasonal changes in malondialdehyde formation as a source of variance in oxidative stress schizophrenia research.

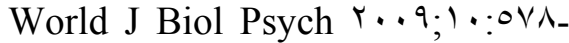
$\wedge$. 